\title{
16. SOURCE AND MATURITY OF ORGANIC MATTER IN SEDIMENTS AND ROCKS FROM SITES 759, 760, 761, AND 764 (WOMBAT PLATEAU) AND SITES 762 AND 763 (EXMOUTH PLATEAU) ${ }^{1}$
}

\author{
Lloyd R. Snowdon ${ }^{2}$ and Philip A. Meyers ${ }^{3}$
}

\begin{abstract}
A summary of shipboard Rock-Eval measurements shows that organic matter in Upper Triassic siltstone from the Wombat Plateau is dominated by Type III kerogen and is thermally immature. Neocomian siltstone from the Exmouth Plateau similarly contain thermally immature Type III organic matter. Overlying Upper Cretaceous to Quaternary carbonates are poor in organic matter at both locations, yet significant amounts of methane-dominated gas are dissolved in the pore waters of the thick carbonate sequence present on the Exmouth Plateau. This dry gas is believed to have migrated from deeper and more mature strata containing Type III kerogen.
\end{abstract}

\section{INTRODUCTION}

The Exmouth and Wombat plateaus, located on the northwestern Australian continental margin (Fig. 1), consist of rifted and deeply subsided continental crust isolated from the continental shelf by the Kangaroo Syncline (Exon et al., 1982). Although basement rocks are covered by Phanerozoic sediments reaching $10 \mathrm{~km}$ in thickness, most of this was deposited prior to rifting, and little terrigenous sediment has accumulated since the Early Cretaceous. Non-commercial gas shows have been found by exploration drilling on the Exmouth Plateau (cf. Barber, 1982). Commercial quantities of hydrocarbons exist nearby; these are located on the continental shelf and on Barrow Island offshore northwestern Australia (cf. Campbell et al., 1984).

Samples of sediments and rocks obtained from the Exmouth and Wombat plateaus by Ocean Drilling Program (ODP) Leg 122 coring were analyzed using the shipboard laboratory facilities to describe their organic geochemical contents. These analyses had two purposes. First, gas-rich sequences were anticipated at several of the outer continental margin sites drilling during Leg 122. Monitoring of the core material for content of gaseous hydrocarbons and type of organic matter was critical for drilling safety. Second, knowledge of the origin and amount of organic matter in sedimentary rocks is helpful in reconstructing the depositional paleoenvironments of the various lithostratigraphic units encountered during drilling.

The results of the shipboard organic geochemical analyses from each of the six sites occupied during Leg 122 are presented in the individual site summary chapters in the Leg 122 Initial Reports volume (Haq, von Rad, O'Connell, et al., 1990). In this report, we summarize and integrate the shipboard organic geochemical information from the individual sites into composites for the major lithostratigraphic types encountered during Leg 122. Sources and thermal maturities

\footnotetext{
1 von Rad, U., Haq, B. U., et al., 1992. Proc. ODP, Sci. Results, 122: College Station, TX (Ocean Drilling Program).

${ }^{2}$ Geological Survey of Canada, 3303 33rd Street NW, Calgary, Alberta T2L 2A7, Canada.

3 Department of Geological Sciences, The University of Michigan, 1006 C.C. Little Building, Ann Arbor, MI 48109-1063, U.S.A.
}

of the organic matter contained in these strata are discussed in terms of these summaries.

\section{SAMPLING AND ANALYSIS}

\section{Sample Selection}

Samples were selected for routine inorganic and organic carbon determinations from cores using two principal criteria: (1) samples chosen for shipboard physical properties measurements, and (2) samples selected for headspace gas analysis. These two types of sampling strategies provided data from a variety of lithologies and from nearly every core. In addition, samples were also selected from sections expected to contain elevated organic matter concentrations and from near interesting lithologic boundaries. In several instances, organic geochemical studies were done on samples from which pore waters had been squeezed.

\section{Analytical Procedures}

Concentrations of inorganic carbon were determined on freeze-dried samples using a Coulometrics 5010 coulometer equipped with a 5030 carbonate carbon analyzer (cf. Engleman et al., 1985). In this instrument, carbonate carbon is converted to $\mathrm{CO}_{2}$ by treatment with $\mathrm{HCl}$, and the amount of liberated $\mathrm{CO}_{2}$ is measured by titration in a mono-ethanolamine solution with a colorimetric indicator. A photo-detection cell is used to monitor the end point. Inorganic carbon concentrations were converted to carbonate percentages, assuming all of the inorganic carbon was present as calcium carbonate.

Total organic carbon (TOC) concentrations were determined as part of the Rock-Eval analysis of samples (cf. Espitalié et al., 1977). The Rock-Eval instrument on the JOIDES Resolution is a Girdel Rock-Eval II equipped with a TOC module. Programmed pyrolysis of samples from $300^{\circ} \mathrm{C}$ to $600^{\circ} \mathrm{C}$ gives the amount of preformed hydrocarbons $\left(S_{1}\right)$, the amount of hydrocarbons released during heating $\left(\mathrm{S}_{2}\right)$, and the amount of $\mathrm{CO}_{2}$ released during pyrolysis to $390^{\circ} \mathrm{C}\left(\mathrm{S}_{3}\right)$. These values provide the bases for calculation of the hydrogen index $(\mathrm{HI})$, where $\mathrm{HI}=100 \times \mathrm{S}_{2} / \mathrm{TOC}$, the oxygen index (OI), where $\mathrm{OI}=100 \times \mathrm{S}_{3} / \mathrm{TOC}$, the production index $(\mathrm{PI})$, where $\mathrm{PI}=\mathrm{S}_{1} /\left[\mathrm{S}_{1}+\mathrm{S}_{2}\right]$, and the concentration of total organic carbon. Samples rich in carbonate and poor in organic matter can yield questionable oxygen index values (cf. Katz, 1983) and must be interpreted cautiously. The temperature of max- 


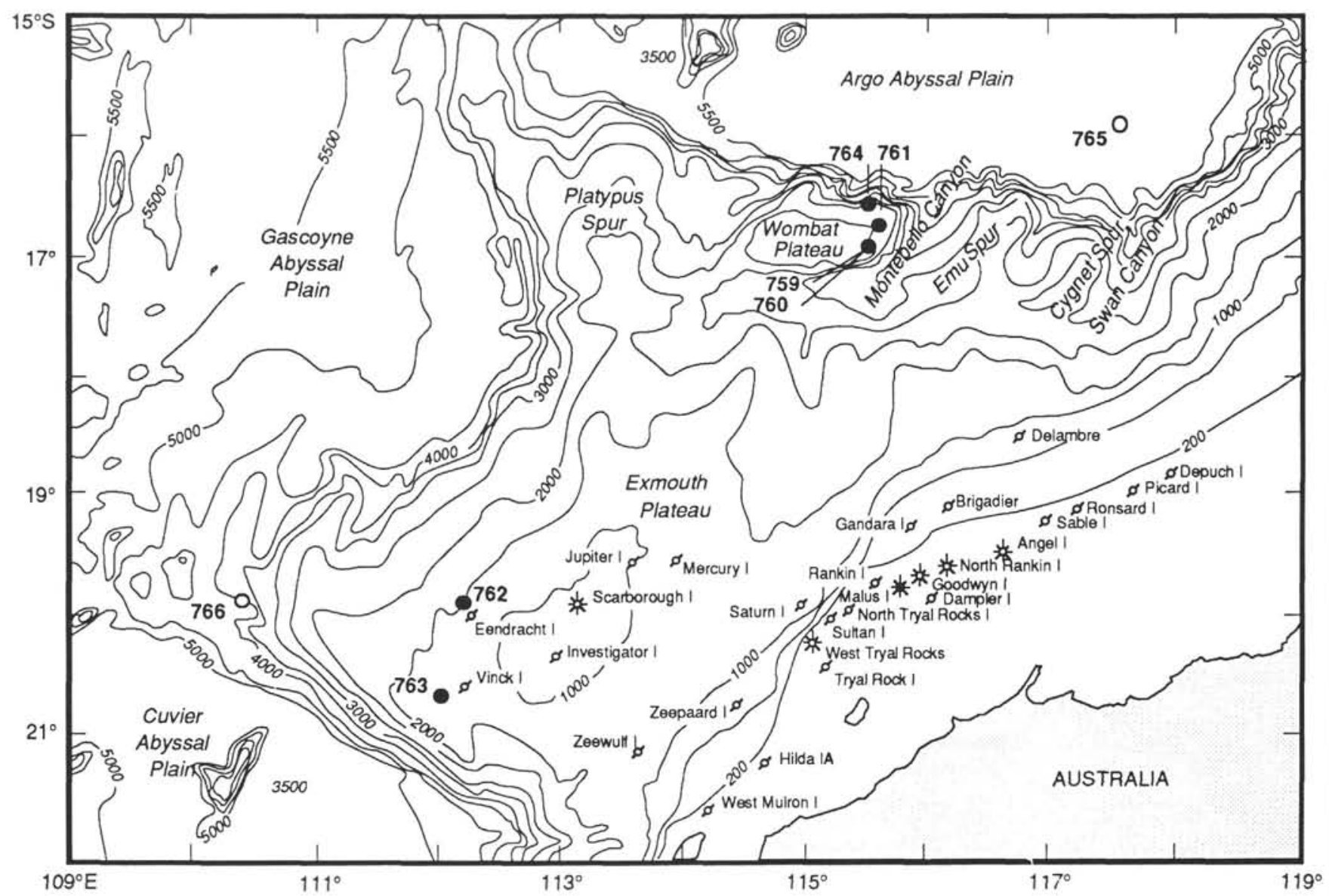

Figure 1. Locations of sites cored during Leg 122 (solid dots) and Leg 123 (open circles). Positions of exploratory wells are indicated; standard industry symbols are used. Water depths given in meters.

imum hydrocarbon release during pyrolysis $\left(\mathrm{T}_{\max }\right)$ is also obtained and can be interpreted as a measure of organic matter thermal maturity. The TOC module combusts the residue of the temperature-programmed sample in air at $600^{\circ} \mathrm{C}$ and sums the product of this oxidation with those of the preceding temperature-programmed pyrolysis to give the total organic carbon.

Descriptions in this report of gaseous hydrocarbons present in sediment pore spaces are obtained from headspace analysis of samples of sediments and rocks. The headspace procedure measures the gases released from a sample contained in a septum-sealed vial during heating at $70^{\circ} \mathrm{C}$ (Kvenvolden and MacDonald, 1985). Gas analyses were done with a Carle AGC 1000/Model 211 gas chromatograph operated isothermally at $80^{\circ} \mathrm{C}$ and equipped with a flame ionization detector. The results are given relative to the headspace volumes of the $15-\mathrm{mL}$ sample containers; they are not absolute indicators of the porespace gas contents.

\section{RESULTS AND DISCUSSION}

\section{Wombat Plateau}

Sites $759,760,761$, and 764 comprise a transect across the Wombat Plateau (Fig. 1). Drilling at each site sampled progressively younger strata as the transect proceeded northward across this tilted and subsided block of continental crust. The results from coring at these sites have been combined to give a composite summary of sediment accumulation at this loca- tion dating back to Late Triassic time (Exon et al., 1989; Williamson et al., 1989). A similar composite summary of total organic carbon concentrations found in sedimentary rocks from Sites 759, 760, and 761 has been constructed to examine changes in organic matter content as a function of stratigraphic unit (Fig. 2). The TOC contents of samples from the thin cover of Tertiary pelagic carbonates and the underlying Rhaetian reef cap at Site 764 are close to zero and thus could not be reliably characterized. They were not used in the construction of this composite section.

The Wombat Plateau composite section consists of an attenuated thickness of Cretaceous and Tertiary carbonate chalks and oozes which covers Rhaetian shallow-water marine to lagoonal sediments dominated by carbonates. The carbonate sequences overlie clastic deltaic sediments of lower-to-middle Carnian to Norian age. The three units contrast both in their carbonate carbon content and in their organic carbon contents (Haq, von Rad, O'Connell, et al., 1990). The carbonates generally contain less than $0.2 \%$ TOC, whereas the Rhaetian lagoonal sediments generally contain more than $0.5 \%$ TOC. The Norian-to-Carnian deltaic clastic sediments typically contain $1 \%$ to $3 \%$ TOC, with occasional samples exceeding $10 \%$ TOC (Fig. 2).

The results of Rock-Eval pyrolysis indicate that the organic matter of the Triassic sediments is dominated by debris from continental higher plants. Samples from these units yield low hydrogen indexes characteristic of Type III kerogen (Fig. 3), which is consistent with the deltaic and lagoonal Late Triassic 
Total Organic Carbon (\%)

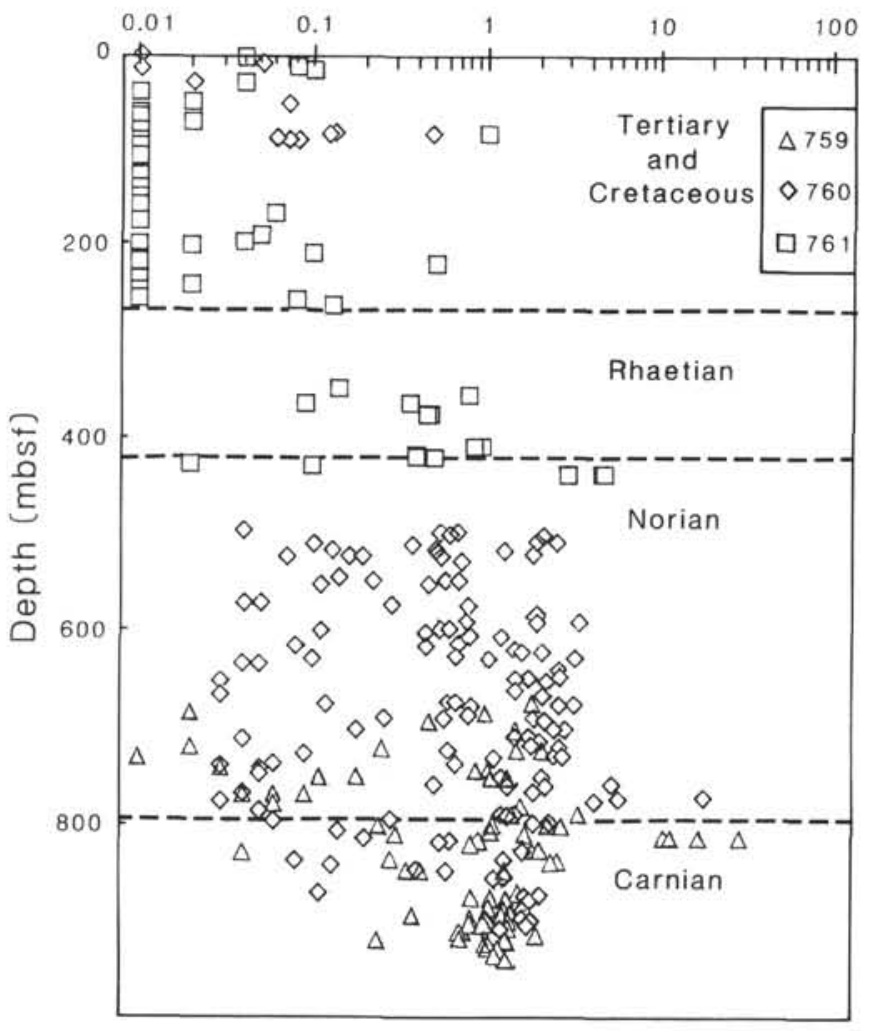

Figure 2. Combined profile of organic carbon concentrations of samples from different lithostratigraphic units of Sites 759, 760, and 761 on the Wombat Plateau. Sub-bottom depths are for a synthesized combined sedimentary column (cf. Williamson et al., 1989) and are not actual drill-hole depths.

paleoenvironments. The Upper Triassic sections encountered in Sites 759, 760, and 761 are equivalent to the Mungeroo Formation which underlies much of the northwestern Australian continental margin. Cook et al. (1985) have petrographically examined the organic matter of this formation in cuttings from the Jupiter and Mercury wells (Fig. 1). They find abundant proportions of vitrinite, which is thermally immature in the upper parts of the formation, as well as coaly stringers.

The organic matter type for the Cretaceous and Tertiary carbonates cannot be reliably determined by Rock-Eval pyrolysis because the TOC and Rock-Eval $\mathrm{S}_{2}$ values are too low to give dependable $\mathrm{HI}$ or $\mathrm{OI}$ values. $\mathrm{By}$ inference from the pelagic nature of the carbonate sediments, however, a marine organic matter source can be assumed. The existence of low TOC concentrations in the Cretaceous and younger sediments implies an environment of low marine production and poor preservation of organic matter throughout this long period of time. Marine biological productivity has remained low off northeast Australia to the present day.

Comparison of $\mathrm{HI}$ values to TOC concentrations reveals a negative trend (Fig. 3), which contrasts with samples from most Deep Sea Drilling Project Mesozoic samples (e.g., Dean et al., 1985). The scatter for samples with less than about $0.5 \%$ TOC probably results from the compounded effects of small absolute analytical errors; uncertainty in measurement of low values of TOC, which appears in the HI denominator, is particularly important in this regard (cf. Katz, 1983). Above $0.5 \% \mathrm{TOC}$, the decrease in $\mathrm{HI}$ with increasing TOC indicates
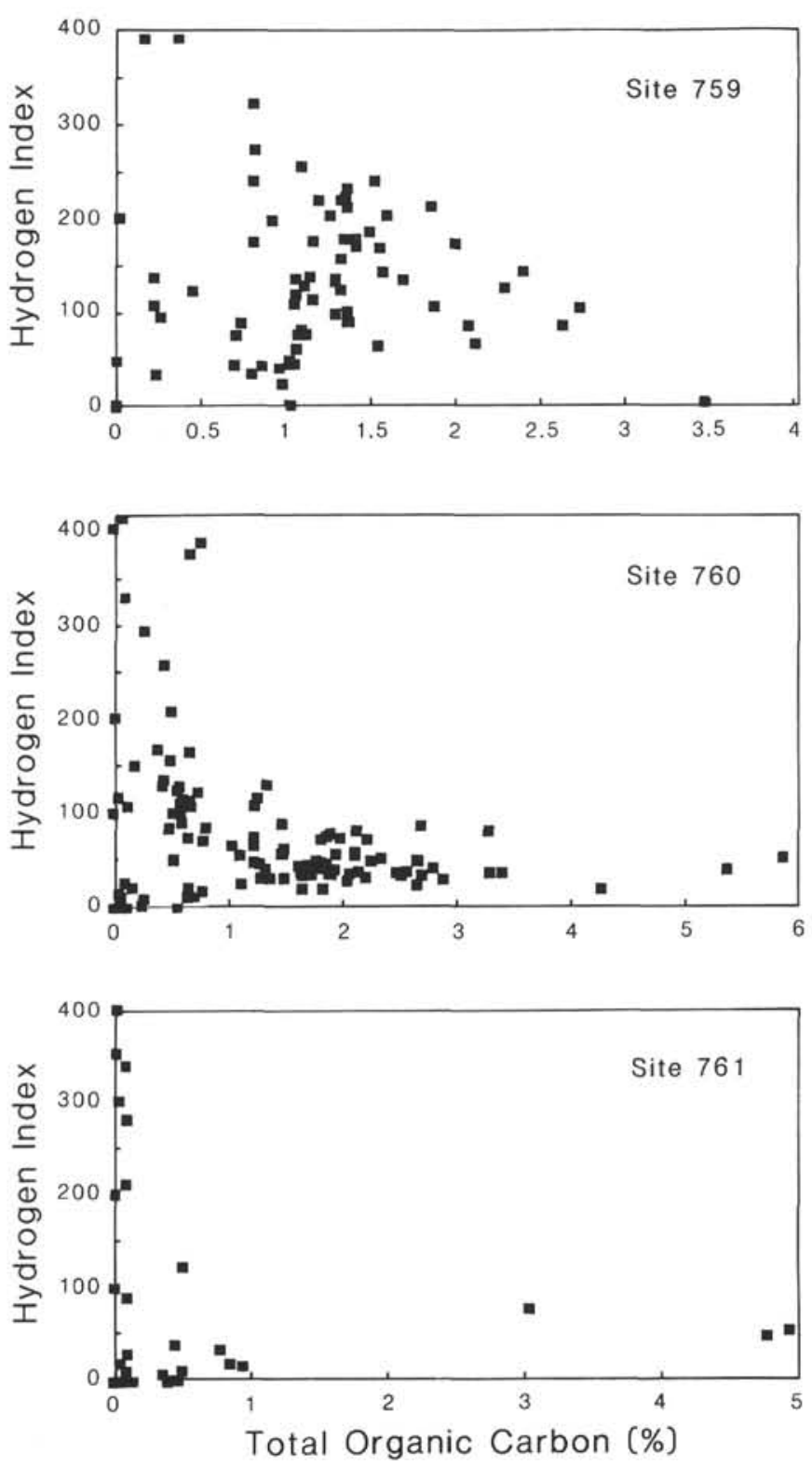

Figure 3. Total organic carbon (TOC) vs. Rock-Eval hydrogen index (HI) values for Sites 759, 760, and 761 on the Wombat Plateau. Note the general decrease in $\mathrm{HI}$ as TOC increases. At TOC values of $<0.25 \%$, HI values are artificially elevated; at higher TOC values, the decrease in $\mathrm{HI}$ indicates greater proportions of land-derived organic matter.

an increase in the proportion of refractory and/or continental Type III organic matter relative to Type II lipid-rich marine or continental material. This change in type of organic matter is especially evident for Site 759 , wherein the effect extends up to $3.5 \%$ TOC and the HI decreases from mixed Type II-Type III to essentially pure Type III. For Site 760 , the HI remains $\sim 70 \mathrm{mg}$ hydrocarbon per gram of organic carbon above a TOC of $\sim 1 \%$, and the type of organic matter appears to be independent of TOC quantity. Almost no deltaic sediments were recovered from Site 761 , but the three clastic samples with TOC contents in excess of $0.5 \%$ also display HI values of about $70 \mathrm{mg}$ hydrocarbon $/ \mathrm{g}$ TOC, indicative of Type III continental organic matter. 
The level of thermal maturity is inferred to be low (that is, at a vitrinite reflectance $\left(\mathrm{R}_{\mathrm{o}}\right)$ level of less than about $\left.0.5 \% \mathrm{R}_{\mathrm{o}}\right)$ for all sites on Wombat Plateau on the basis of low Rock-Eval $\mathrm{T}_{\max }$ and $\mathrm{PI}$ values (about $425^{\circ} \mathrm{C}$ and $0.06 \mathrm{mg}$ hydrocarbon per g TOC, respectively), as well as the unmetamorphosed lithologic character of the sediments. Vitrinite reflectance measurements ranging between $0.25 \%$ and $0.41 \%$ for three Triassic samples from Sites 759 and 760 (Table 1) verify the inferred low maturity and are consistent with the petrographic data of Cook et al. (1985). Vitrinite reflectance measurements on samples from the Jupiter and Mercury wells range between $0.2 \%$ and $0.5 \% \mathrm{R}_{\mathrm{o}}$ in the upper sections of the Mungeroo Formation (Barber, 1982), which is equivalent to the Upper Triassic siltstones of Sites 759, 760, and 761. Although the limited vitrinite data suggest an increase in maturity with depth and agree with the trend observed by Barber (1982), the extensive downcore scatter of Rock-Eval $T_{\max }$ results (Fig. 4) indicates large proportions of reworked, geologically recycled or oxidatively degraded organic matter in all lithologic units from the three sites, making impossible any conclusion about a downcore maturity trend in these Leg 122 samples. The low thermal maturity typical of the Wombat Plateau sedimentary rocks implies that these deposits have never been deeply buried and that erosion of younger strata has not been extensive.

The headspace gas content for all drill sites on the Wombat Plateau remained low, with most samples yielding essentially blank or background levels of about $3 \mathrm{ppm}$ methane. A few samples near the bottoms of the holes yielded small amounts of higher homologs of methane, along with the low $C_{1} / C_{2}$ ratios expected for a thermogenic rather than biogenic source (Claypool and Kvenvolden, 1983). Because the level of thermal maturity was low (less than about $0.5 \%$ vitrinite reflectance), the small amount of gas which was present was inferred to result from either incipient in-situ gas generation or migration from deeper strata.

\section{Exmouth Plateau}

Coring at Sites 762 and 763 on the Exmouth Plateau passed through an upper section of Quaternary, Tertiary, and Upper Cretaceous oozes and chalks with very low TOC contents (Fig. 5), through an early Aptian dark-colored calcareous claystone equivalent to the Muderong Shale, and into Neocomian black-colored siltstones equivalent to the Barrow Formation. As with the Wombat Plateau samples, the organic carbon content is inversely related to the carbonate carbon content. Almost all of the samples of carbonate ooze and chalk contain less than $0.1 \%$ TOC, whereas nearly all of the clastic samples have more than $0.5 \%$ TOC. The siltstones equivalent to the Barrow Formation typically contain about $1 \%$ TOC (Fig. 5), with a few samples having up to $1.5 \%$ at Site 762 and up to $2 \%$ TOC at Site 763.

Two thin layers $(4 \mathrm{~cm}$ and $12 \mathrm{~cm})$ of organic-carbon-rich black claystones were encountered at the Cenomanian/Turonian boundary at Site 763 . Organic carbon measures as high as $15 \%$ in the thinner of these layers and $9 \%$ in the thicker (Haq,

Table 1. Vitrinite reflectance measurements $\left(\% R_{0}\right)$ made by $W$. Kalkreuth at the Geological Survey of Canada.

\begin{tabular}{cccccccr}
\hline $\begin{array}{c}\text { Hole, core, } \\
\text { section }\end{array}$ & $\begin{array}{c}\text { Depth } \\
(\mathrm{mbsf})\end{array}$ & Age & $\begin{array}{c}\mathrm{R}_{\mathrm{o}} \\
\%\end{array}$ & $\begin{array}{r}\text { TOC } \\
(\%)\end{array}$ & $\begin{array}{r}\mathrm{T}_{\max } \\
\left({ }^{\circ} \mathrm{C}\right)\end{array}$ & HI & OI \\
\hline $122-759 \mathrm{~B}-17 \mathrm{R}-1$ & 145 & Norian & 0.25 & 7.35 & 442 & 11 & 49 \\
$122-760 \mathrm{~B}-19 \mathrm{R}-2$ & 409 & Norian & 0.38 & 29.80 & 434 & 22 & 60 \\
$122-760 \mathrm{~B}-22 \mathrm{R}-2$ & 437 & Carnian & 0.41 & 14.55 & 424 & 93 & 49 \\
\hline
\end{tabular}

TOC $=$ total organic carbon $; \mathrm{HI}=$ hydrogen index $; \mathrm{OI}=$ oxygen index. von Rad, O'Connell, et al., 1990). Rock-Eval pyrolysis indicates that these layers contain Type II marine organic matter. These two layers deviate from the overall concentration trends of increasing $\mathrm{CaCO}_{3}$ and decreasing TOC as the Exmouth Plateau subsided through Cretaceous and Tertiary time and as water paleodepths increased. Cenomanian-Turonian boundary sediments were also recovered at Site 762, but they are carbonates containing $\sim \mathbf{0 . 0 1 \%}$ TOC (Haq, von Rad, O'Connell, et al. 1990).

Organic carbon concentrations vary within the Neocomian siliciclastic fluviodeltaic unit corresponding to the upper part of the Barrow Formation (Fig. 5). The downcore decrease and then increase in the TOC content may reflect variable oxidation of organic matter in these sections at Sites 762 and 763. Increased levels of oxidative degradation could be related to an increased grain size and concomitant increase in the circulation of oxygen-bearing water into the sediment. Higher accumulation rates of sediment should be accompanied by a higher flux of organic debris, and thus clastic dilution is not a likely explanation for the observed TOC trend.

Rock-Eval data from Sites 762 and 763 are similar (Fig. 6), yet a significant difference exists in samples from the two locations. Samples from Site 762 with $>0.5 \%$ TOC show a constant $\mathrm{HI}$ of between 50 to 100 , typical of Type III, higher land plant organic matter. Samples from Site 763, on the other hand, show a small but definite increase in $\mathrm{HI}$ with increasing TOC content, and TOC concentrations are somewhat higher in sediments from this site. The difference between the two sites is consistent with differential preservation being an important control of the TOC concentration: where degradation is less, preservation of hydrogen-rich lipid material is improved. The essentially constant and low HI values of the samples from the stratigraphic unit at Site 762 equivalent to the onshore Barrow Formation may have resulted from extensive degradation of organic matter which accompanied a low sedimentation rate. The resultant lengthened exposure time within the bioturbated sediment-water interface would allow preservation of only the most refractory portions of the deposited organic debris (cf. Emerson and Hedges, 1989).

In Figure 6, some of the samples having only a few tenths of a percent of organic carbon display high $\mathrm{HI}$ values $(>300$ mg hydrocarbon/g organic carbon). These values are probably spurious, arising from small but multiplicative analytical errors in the TOC and $S_{2}$ measurements of these samples. They are included here as an illustration of a potential limitation of the Rock-Eval procedure to samples low in TOC and high in $\mathrm{CaCO}_{3}$ (cf. Katz, 1983), which are common to ODP coring.

The level of thermal maturity indicated by the Rock-Eval $\mathrm{T}_{\max }$ parameter for the deltaic Barrow Formation siltstones is immature to marginally mature. $T_{\max }$ values are about $410^{\circ}$ to $425^{\circ} \mathrm{C}$ (equivalent to a vitrinite reflectance of $0.4 \%$ to $0.5 \% \mathrm{R}_{\mathrm{o}}$ ) for Site 762 with no discernible trend over the relatively short depth interval of samples from the Barrow Formation. In contrast, $\mathrm{T}_{\max }$ values increase at Site 763 over a $400-\mathrm{m}$ interval from about $422^{\circ} \mathrm{C}$ to about $430^{\circ} \mathrm{C}$ (equivalent to about $0.45 \%$ to $\left.0.60 \% \mathrm{R}_{\mathrm{o}}\right)$. This trend may represent a true increase in thermal maturation with depth, or it alternatively reflects a shift in the type of organic matter. Thermal maturation modeling done at the Geological Survey of Canada using the Institut Francais du Petrole software package MATOIL indicates that the heat flow at this site would need to have exceeded $120 \mathrm{~mW} / \mathrm{m}^{2}$ since the Neocomian in order to attain a vitrinite reflectance in excess of $0.5 \% \mathrm{R}_{\mathrm{o}}$. Physical properties measurements (Haq, von Rad, O'Connell, et al., 1990) indicate a contemporary heat flow of about $75 \mathrm{~mW} / \mathrm{m}^{2}$ for the uppermost $150 \mathrm{~m}$ of Site 763 , which is far too low to have achieved the thermal maturity indicated by the Rock-Eval $\mathrm{T}_{\max }$ data. Instead of 


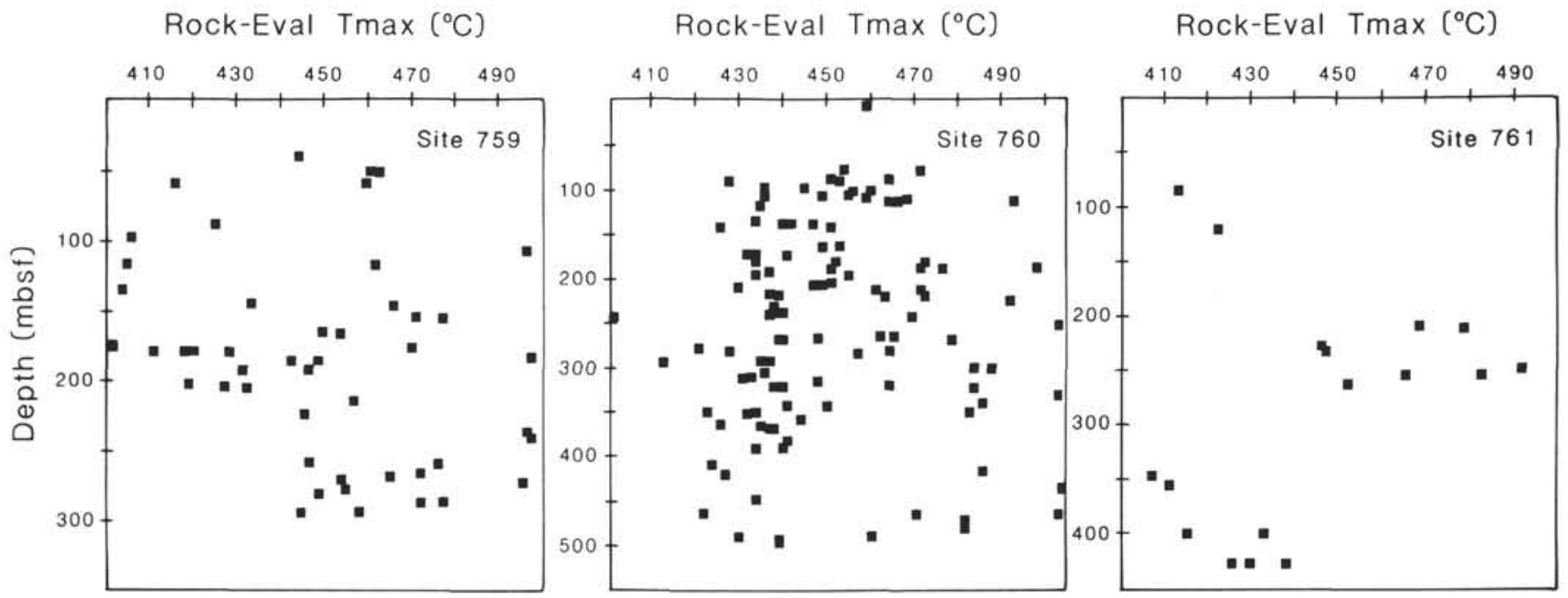

Figure 4. Rock-Eval $T_{\max }$ values as a function of depth for Sites 759, 760, and 761 on the Wombat Plateau. Extensive scatter of the results is interpreted to be the result of recycled and oxidatively degraded (reworked) organic matter dominating the sediments. The actual level of thermal maturity is interpreted to be low and is estimated to be equivalent to a vitrinite reflectance of less than $0.5 \% \mathrm{R}_{\mathrm{o}}$ or $\mathrm{T}_{\max }$ less than $425^{\circ} \mathrm{C}$.

Total Organic Carbon (\%)

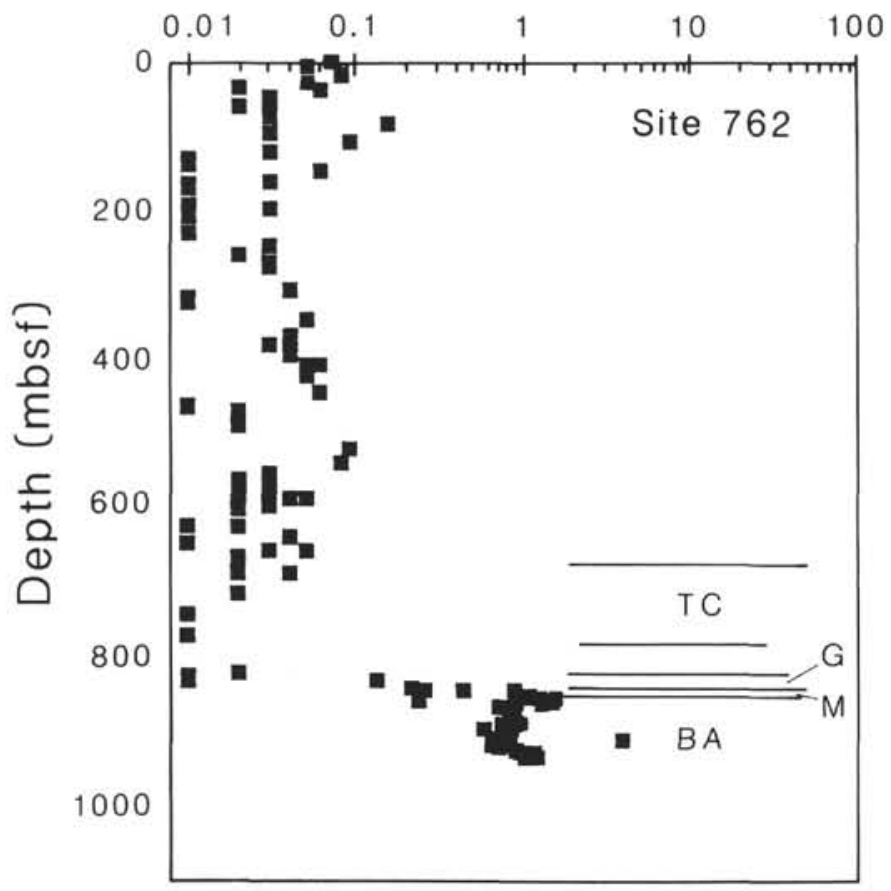

Total Organic Carbon (\%) $\begin{array}{lllll}0.01 & 0.1 & 1 & 10 & 100\end{array}$

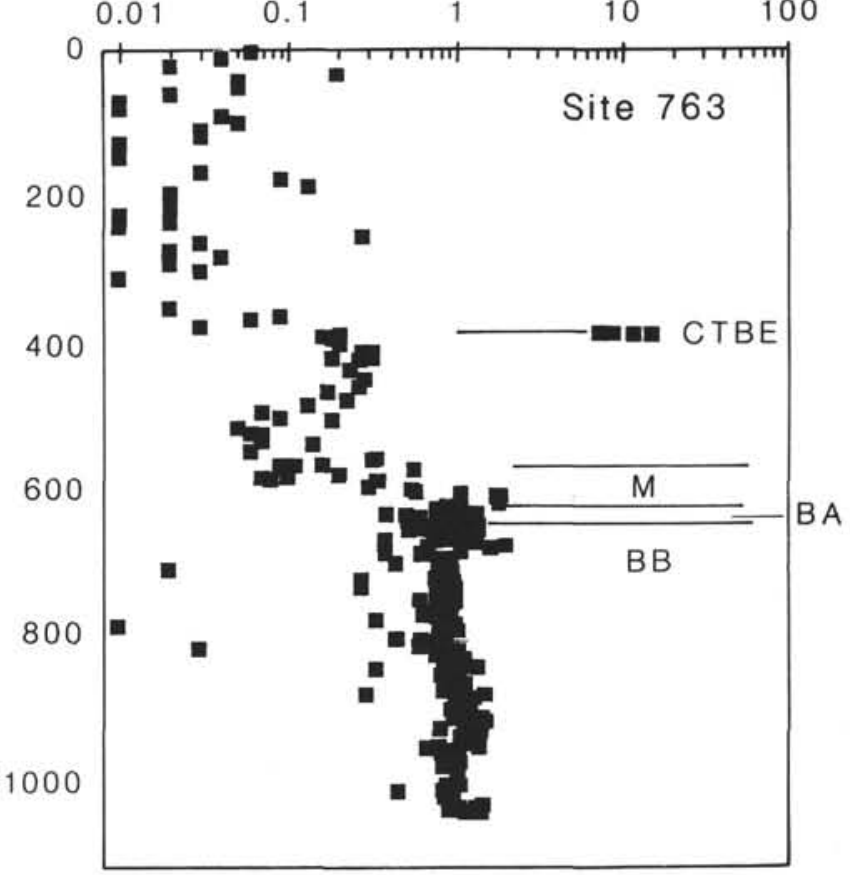

Figure 5. Total organic carbon vs. depth for Sites 762 and 763 on the Exmouth Plateau. Rock units equivalent to strata identified on northeastern Australia are indicated: Toolonga Calcilutite (TC); Gearle Siltstone (G); Muderong Formation (M); Barrow "A" Formation (BA); Barrow "B" Formation (BB). An unnamed unit exists between 780 and $815 \mathrm{mbsf}$ in the Site 762 sedimentary column. The Cenomanian/Turonian Boundary Event (CTBE) appears with its characteristic TOC enhancement at 380 mbsf in the Site 763 column.

in-situ thermal maturation, the increasing $\mathrm{T}_{\max }$ values may indicate the presence of an increasingly larger contribution of recycled, geologically old, detrital organic matter in the progressively deeper deltaic siltstones. A larger proportion of land-derived organic matter is consistent with sedimentological evidence that the older siltstones were deposited in shallower waters closer to ancient shorelines (Haq, von Rad, O'Connell, et al., 1990).
Concentrations of headspace gas of up to $100,000 \mathrm{ppm}$ were found over the intervals of 500 to 800 mbsf in Hole $762 \mathrm{C}$ and of 300 to 600 mbsf in Hole 763B (Fig. 7). The gas was generally quite dry in these intervals, having $C_{1} / C_{2}$ ratios of 5,000 to 10,000 . High $C_{1} / C_{2}$ ratios are usually interpreted as indicating biogenic gas (cf. Claypool and Kvenvolden, 1983), yet they can also indicate a thermogenic origin from gas-prone, terrigenous organic matter (Hunt, 1979, p. 438). As gas concentrations 

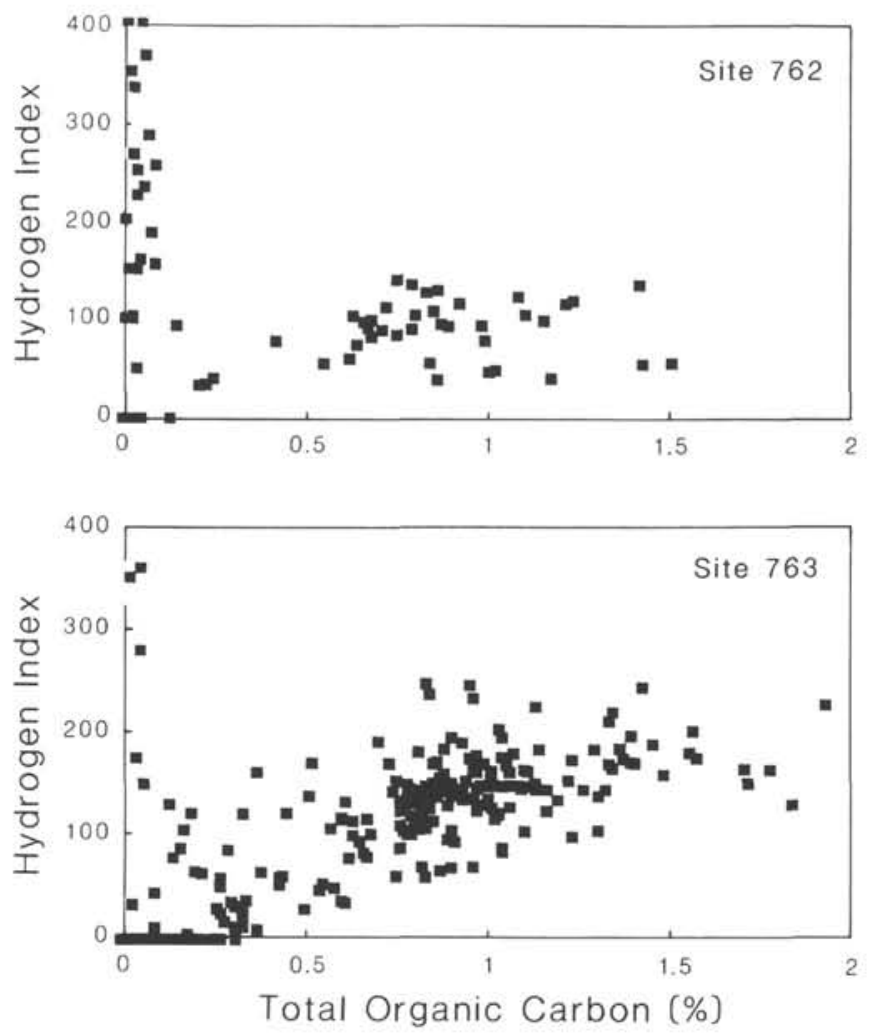

Figure 6. Rock-Eval hydrogen index vs. total organic carbon for Sites 762 and 763 on Exmouth Plateau. HI values in excess of about $300 \mathrm{mg}$ hydrocarbon/g organic carbon are interpreted to be artifacts due to small analytical errors in TOC values $<0.25 \%$.

decreased below the gas-rich intervals, $\mathrm{C}_{1} / \mathrm{C}_{2}$ ratios diminished. At the same time, contributions of $\mathrm{C}_{3}$ to $\mathrm{C}_{6}$ hydrocarbons began to increase (Haq, von Rad, O'Connell, et al., 1990). The appearance of the latter constituents suggests that the source of the gases in these holes was being approached.

The headspace gas results for Sites 762 and 763 appear to correlate with the level of lithification or cementation rather than the organic carbon content or thermal maturity. At 350 mbsf in Hole 762C and at 300 mbsf in Hole 763B, concentrations of $\mathrm{CaCO}_{3}$ decrease from $\sim 90 \%$ to between $35 \%$ and $80 \%$ whereas TOC values remain unchanged at $<0.1 \%$. The two to three order of magnitude increase in headspace gas content more or less coincides with the change from ooze to chalk and occurs well above the organic-rich clastic section of these two sites. Although the TOC is low $(<0.1 \%)$ in the carbonatedominated section, sufficient carbon may be available for the generation of biogenic methane, which is characterized by the high ratio of methane to ethane $\left(C_{1} / C_{2}>10,000\right)$. Alternatively, preferential migration of methane relative to heavier gases (Leythaeuser et al., 1982, 1983) from a deeper source may have created the elevated $C_{1} / C_{2}$ ratios. Toward the bottom of both holes, this ratio decreases with the introduction of thermogenic gas. The low to marginal levels of thermal maturity indicated by the gas data are consistent with the $\mathrm{T}_{\max }$ results discussed above.

Vertical migration of a major proportion of these gases is inferred from several lines of evidence. First, the very low concentrations of organic carbon throughout most of these sediments precludes local generation. Second, the increase in headspace concentrations by three orders of magnitude over relatively short depth intervals implies movement into these intervals. Third, the appearance of gas chimneys on seismic reflection profiles of these sections identifies conduits facilitating gas movement. The high $C_{1} / C_{2}$ ratios are believed to derive largely from thermogenic breakdown of Type III organic matter, and the gases probably originated from the Jurassic coal seams or from the Triassic Mungeroo Formation underlying these sites. Barber (1982) reports a $\delta^{13} \mathrm{C}$ value of $-40 \%$ for methane-rich gas sampled from the Upper Triassic Brigadier Bed above the Mungeroo Formation in the Jupiter well. The molecular and isotopic compositions of this gas suggest a thermogenic origin from Type III kerogen (Hunt, 1979, p. 178).

The presence of the elevated concentrations and the decreasing-with-depth trend of the $C_{1} / C_{2}$ ratios in the headspace gases at both of these sites presented safety concerns during drilling. Continuance of drilling was based on several considerations. First, gas logs from the nearby and structurally higher Eendracht and Vinck exploration wells (Fig. 1) showed no evidence of free gases or of overpressuring. Second, no porous reservoir unit existed above the postulated source of the gaseous hydrocarbons. Nonetheless, when gas concentrations suddenly increased by a factor of nearly ten in the last two cores cut from Hole 763B (Fig. 7), drilling was discontinued.

\section{CONCLUSIONS}

The organic matter content of the Upper Triassic sediments of Wombat Plateau is moderate (about $1 \%-3 \%$ TOC) and is dominated by Type III kerogen derived from higher land plant debris, which is common for paralic to deltaic sediments. The thermal maturity of samples recovered from Sites 759, 760, and 761 is below the level necessary for significant hydrocarbon generation. Sediments of this character, however, contain adequate organic matter to generate and expel commercially interesting amounts of gaseous hydrocarbons if subjected to higher thermal stress than found on the Wombat Plateau.

Exmouth Plateau Sites 762 and 763 yielded samples of Neocomian siltstones from stratigraphic units equivalent to the onshore Barrow Formation which are dominated by Type III organic matter and which also appear to contain hydrocarbon-richer material in some intervals. The consequent hydrogen enrichment confers a limited enhanced potential to generate and to expel liquid as well as gaseous hydrocarbons. Organic matter in the Exmouth Plateau samples is immature to marginally mature. Gaseous hydrocarbons in sediments of Sites 762 and 763 are abundant and are dominated by methane through most of the lithologic units. Deeper gases contain significant amounts of thermogenic $\mathrm{C}_{2}$ to $\mathrm{C}_{6}$ hydrocarbons. The source of these gases appears to be from Type III organic matter in deeper strata, and upward migration has resulted in preferential enrichment of methane.

\section{ACKNOWLEDGMENTS}

We appreciate the comments of J.-P. Herbin, which helped improve this contribution. We thank W. Kalkreuth for kindly performing vitrinite reflectance measurements for this study and E. S. Ho for reviewing an early version of this paper. LRS and PAM are paradoxically grateful for the opportunity to have spent nine weeks at sea on the JOIDES Resolution during ODP Leg 122.

\section{REFERENCES}

Barber, P. M., 1982. Paleotectonic evolution and hydrocarbon genesis of the central Exmouth Plateau. APEA J., 22:131-144.

Campbell, I. R., Tait, A. M., Reiser, R. F., 1984. Barrow Island oilfield, revisited. APEA J., 24:289-298.

Claypool, G. E., and Kvenvolden, K. A., 1983. Methane and other hydrocarbon gases in marine sediment. Annu. Rev. Earth Planet. Sci., 11:299-327. 
Cook, A. C., Smyth, M., and Vos, R. G., 1985. Source potential of Upper Triassic fluvio-deltaic systems of the Exmouth Plateau. APEA J., 25:204-215.

Dean, W. E., Arthur, M. A., and Claypool, G. E., 1985. Depletion of ${ }^{13} \mathrm{C}$ in Cretaceous marine organic matter: source, diagenetic, or environmental signal? Mar. Geol., 70:119-157.

Emerson, S., and Hedges, J. I., 1989. Processes controlling the organic carbon content of open ocean sediments. Paleoceanography, 3:621-634.

Engleman, E. E., Jackson, L. L., and Norton, D. R., 1985. Determination of carbonate carbon in geological materials by coulometric titration. Chem. Geol., 53:125-128.

Espitalié, J., Laporte, J. L., Leplat, P., Madec, M., Marquis, F., Paulet, J., and Boutefeu, A., 1977. Méthode rapide de caractérisation des roches mères, de leur potentiel pétrolier et de leur degrée d'évolution. Rev. Inst. Fr. Pet., 32:23-42.

Exon, N. F., von Rad, U., and von Stackelberg, U., 1982. The geological development of the passive margins of the Exmouth Plateau off northwest Australia. Mar. Geol., 47:131-152.

Exon, N. F., Williamson, P. E., von Rad, U., Haq, B. U., O'Connell, S., 1989. Ocean drilling finds Triassic reef play off NW Australia. Oil \& Gas J., 87:46-52.

Haq, B. U., von Rad, U., O'Connell, S., et al., 1990. Proc. ODP, Init. Repts., 122: College Station, TX (Ocean Drilling Program).
Hunt, J. M., 1979. Petroleum Geochemistry and Geology: San Francisco (W. H. Freeman).

Katz, B. J., 1983. Limitations of "Rock-Eval" pyrolysis for typing organic matter. Org. Geochem., 4:195-199.

Kvenvolden, K. A., and McDonald, T. J., 1985. Gas hydrates in slope sediments of the Middle America Trench, DSDP Leg 84. In von Huene, R., Aubouin, J., et al., Init. Repts. DSDP, 84: Washington (U.S. Govt. Printing Office), 667-682.

Leythaeuser, D., Schaefer, R. G., and Pooch, H., 1983. Diffusion of light hydrocarbons in subsurface sedimentary rocks. AAPG Bull., 67:889-895.

Leythaeuser, D., Schaefer, R. G., and Yukler, A., 1982. Role of diffusion in primary migration of hydrocarbons. AAPG Bull., 66:408-429.

Williamson, P. E., Exon, N. F., Haq, B. U., von Rad, U., and Leg 122 Shipboard Scientific Party, 1989. A Northwest Shelf Triassic reef play: results from ODP Leg 122. APEA J., 29:328-344.

Date of initial receipt: 12 March 1990

Date of acceptance: 13 March 1991

Ms 122B-131

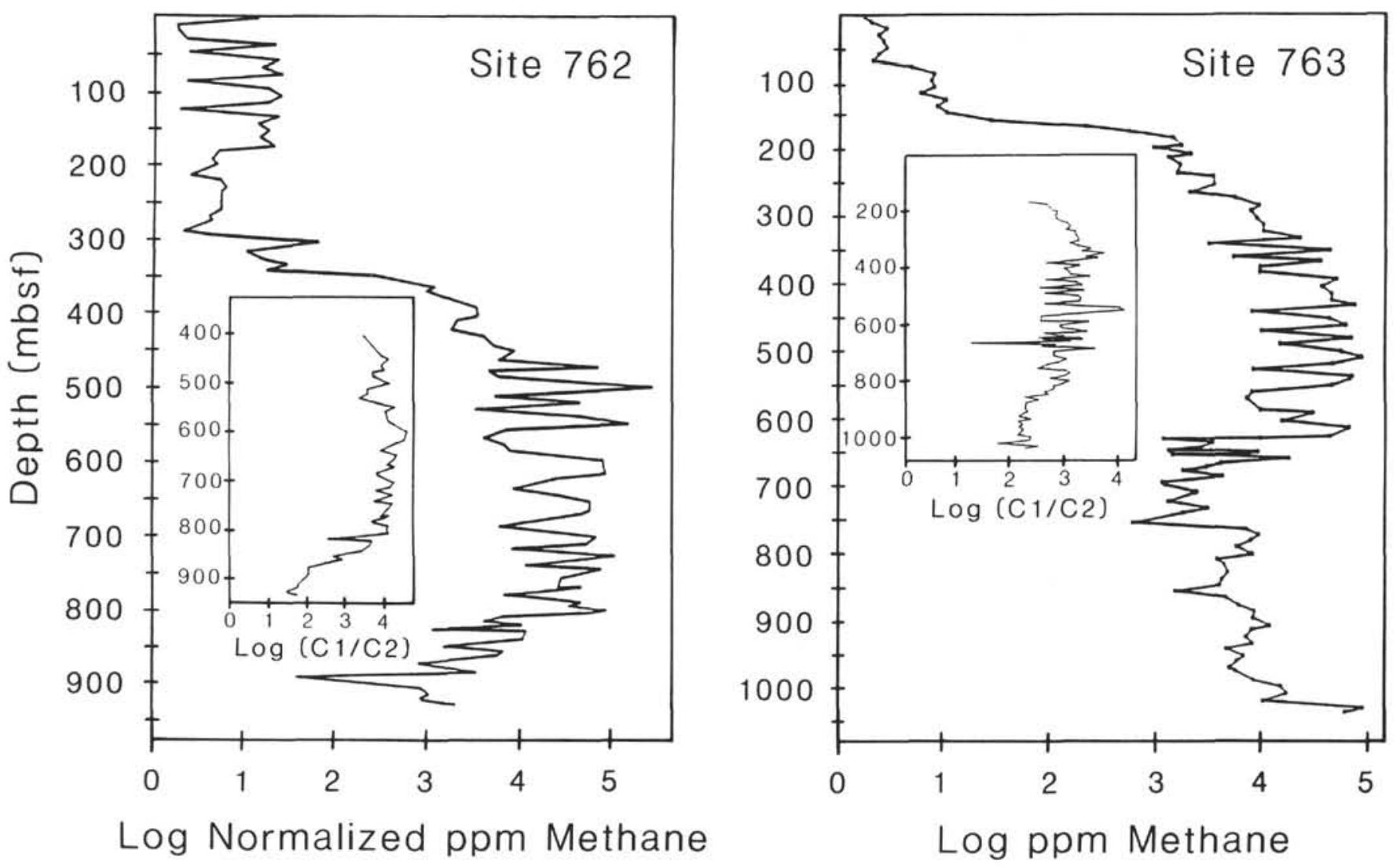

Figure 7. Concentrations and $C_{1} / C_{2}$ ratios of headspace gases in sediments at different depths from Sites 762 and 763 on the Exmouth Plateau. Concentrations of Site 762 gas have been normalized to a uniform headspace volume as described in Haq, von Rad, O'Connell, et al. (1990). 